\title{
RECENT LAND COVER CHANGES IN LATVIA
}

\author{
Endijs Bāders, Mārtiṇš Lūkins, Juris Zariṇš, Oskars Krišāns, Āris Jansons, Jurğis Jansons \\ Latvian State Forest Research Institute ‘Silava’, Latvia \\ endijs.baders@silava.lv
}

\begin{abstract}
Increase in use of biomass as renewable source of energy in Europe is tightly linked to the policies aimed at mitigation of climate changes i.e. reductions of greenhouse gas emissions. Both for assessment of the carbon sequestration and emissions as well as for assessment of potential amounts of biomass for renewable energy, information of land cover dynamics are essential. Therefore, the aim of our study was to improve accuracy of estimates of the land use changes in the time period between 1990 and 2014.

Land use categories were determined in accordance to UNFCCC: wetland, cropland (arable land, bare field), forest, grassland, settlements (urban/suburban area), and other land. Combination of data from National forest inventory (NFI) sample plots and analysis of Landsat images were used. For the classification based on Landsat images vegetation index (NDVI) was estimated and linked to known information on the land use type from NFI sample plot data.

In the analysed period, the most significant changes were found for forest lands - the total area of forest land during the last two decades had increased by 1\% (64.5 thousand ha). Similar increase (1.2\%) was observed also in the area of cropland. Both of these tendencies were primarily the result of marginal field area reduction (by $2.6 \%$ ). Increase in forest area and thus annual increment has led to an increase in above-ground biomass by $10.2 \mathrm{~m}^{3} \mathrm{ha}^{-1}$.

Key words: forest inventory, change mapping, remote sensing, landsat.
\end{abstract}

\section{Introduction}

Reliable information on landscape and its dynamics over time has been critical for managing and supporting related political decisions. Land cover and land use changes are inevitable phenomena due to the action and interaction of natural and human factors (Council of Europe, 2000). During the past decade of remote sensing history, a significant progress of satellite remote sensing methods (Huang et al., 2010) has provided a unique, continuous record of earth observation (Main-Knorn et al., 2013). Moreover, since the recent opening of the Landsat archive by the United States Geological Survey (USGS), it has proven to be of unmatched value in the monitoring and modelling of global land cover and land use change (Wulder et al., 2012). Land cover and land use changes contribute key information about the process that results in landscape transformation (Lambin et al., 2001). Land marginalization and intensification lead to changes in the land use patterns over Europe (Jongman, 1996). Particularly in the former Soviet Union countries where paludification of the drained agricultural land as a legacy of extensive agriculture as well as former cropland overgrowing into forest lands, affected carbon fluxes (Kuemmerle et al., 2011).

Land cover and land use change is the most dynamic driving factor of terrestrial carbon stock change (Schulp et al., 2008). According to the United Nations Framework Convention on Climate Change, countries are required to report annually their greenhouse gas emissions (GHG) and stock changes (UNFCCC, 1997). Therefore, a consistent information of the carbon sequestration and emissions, including assessment of potential amounts of biomass such as for renewable energy and information of land cover and land use change dynamics is essential in carbon stock change and GHG emission from Land Use, Land-Use Change and Forestry (LULUCF) sector modelling and in relation to supporting political decisions (Dhillon \& Wuehlisch, 2013).

The methodological guidance of LULUCF is still insufficient. Up to now the GHG emissions calculations in Latvia have been based on data of moderate spatial $(30 \mathrm{~m})$ resolution satellite images classified by the unsupervised method. The main objective of land cover and land use analysis for Latvia is to understand better the extent of land cover evolution and dynamics in the country over the past two decades. Therefore, the aim of our study was to improve accuracy of estimates of the land use changes in the time period between 1990 and 2014. In addition, after a complete digitizing of the sample plots and their sectors of the National Forest Inventory in 2015, it was possible to describe land cover and land use change since 1990 more accurately.

\section{Materials and Methods}

Data and pre-processing

The framework of this research has been based on two types of data: the land cover and land use category change analysis between first (I) and second (II) National Forest Inventories (NFI) cycle, that cover the time period from 2004 to 2013 and analysis of a time series of the Landsat TM data covering the years 1990 to 2000 to monitor land cover changes using remote sensing and GIS techniques.

The NFI statistical data of forest resources in Latvia and spatial coordinates from all NFI permanent 
sample plots to identify land cover changes that occurred from 2004 to 2013 all over the territory of Latvia, were used. The NFI has been performed in Latvia since 2004 and it is based on the method of continuous sampling where the sampling unit is a sample plot with radius $12.62 \mathrm{~m}$ (Jansons, 2006).

We obtained only cloud-free Landsat 5 TM and 7 ETM+ (L1) systematic and terrain corrected image data, with a $30 \mathrm{~m}$ spatial resolution and UTM projection (zone 36N WGS84). Altogether 27 Landsat scenes from May to August within the geographical extent of Landsat World Reference Paths 185 - 190, Rows 20 - 21 were used. The satellite images were geo-registered to the LKS-92 coordinate system (using a resampling algorithm (Cubic Convolution)). A five-year interval (1990, 1995 and 2000) to identify land cover changes that occurred from 1990 to 2000 was used. Landsat images had a nominal starting year of 1989 and an ending year 2000 due to limited data availability (cloud-free scenes), the actual temporal intervals between consecutive acquisitions can be different from the nominal interval (Huang et al., 2010). As a result, for each five-year time step we also used a closest possible date with cloud-free image (still keeping consistency in seasonality)

Data analysis and classification methods

To compare land use change between both NFI observation cycles we used 'Tabulate Intersection' tool in ESRI ArcMap 10.2., where land use categories for each sample plot of the I NFI cycle was used as the input zone features, while land use categories for each sample plot of the II NFI cycle was as the input class features. We calculated how much of the zone was intersected by each class (area, ha).

Historic land use changes before measurements of the NFI were analysed with supervision classification, e.g. the maximum likelihood classification method (MLC) (Jensen, 2005). We used six categories such as croplands (bare soil and agriculture), other lands, settlements (urban areas/ suburban areas), forest, wetlands and grasslands based on the United Nations Framework Convention on Climate Change (Mollicone et al., 2003). For each category within every Landsat scene at least 20 ground truth polygons were digitized and a signature file with spectral attributes created (Jensen, 2005). The supervision classification was performed in ESRI ArcMap 10.2. software.

Assessment of the loss of live biomass

We obtained the total live aboveground biomass from the NFI database for I and II cycles. The loss of the living biomass between I and II NFI cycles was calculated comparing the wood yields only in those areas where changes of the land cover and land use were detected. We distinguished separately those areas which were transformed into croplands, urban areas or grasslands as well as where the transformation was carried out in naturally afforested areas and in areas where the forest was grown before 1990. Yield stock changes were calculated using spatial layers (as .shp files) with information of the land cover and land use categories from the database of the NFI sample plots in the attribute table. We used 'Intersect' tool in ESRI ArcMap 10.2. to combine information of the wood volume for both cycles in one spatial layer and then calculated differences among them. Area for each sample plot and the wood yield $\left(\mathrm{m}^{3} \mathrm{ha}^{-1}\right)$ for plot was extrapolated to its represented area and national level using conversation coefficient $0.7991807214 \mathrm{~m}^{2} \mathrm{ha}^{-1}$. Finally, in those sample plots where land cover and land use transformation were detected, we calculated differences between I and II cycle and divided by the area in which the land-use change was detected, thereby obtaining a mean yield change. To describe the land cover and land use change after 2011 (for the time period from 2012 to 2014) we extrapolated measurements of the last five years based on linear extrapolation method of Intergovernmental panel on climate change (IPCC, 2014).

\section{Results and Discussion}

Land cover and land use change in the time period from 1990 to 2014

During the last hundred years in Latvia landscape has experienced major transformation from agricultural land to forest area. In 1935, the share of agricultural land in the whole territory of Latvia was $57.3 \%$ and forests occupied $26.6 \%$ of the land area (Bell et al., 2009). Ongoing changes in the political systems in the country towards a harsh policy on the development of land-use structure during the Soviet period (1940 - 1991) like collectivization of agriculture followed by deportations and the centralization of settlements (Nikodemus et al., 2005). During the Soviet period from 1970 to late 80s in Latvia agricultural role decreased and production was more and more imported from other Soviet countries (Krumins, 2012) that caused a gradual decrease of agriculture land area (Mander \& Palang, 1994). The classification result of 1990 satellite images shows that most of the areas were forest covered - 49.2\% of the land area (a total area of Latvia is $64573 \mathrm{~km}^{2}$ ), grasslands covered $26.3 \%$ and cropland occupied $11.5 \%$ (Figure 1).

After the restoration of independence, the land restitution and privatization in 1992 - 1999 resulted in the return of land to its previous owners. Our results are consistent with the continuing decline of cropland area over the study area. We detected that in a continuous five-year period the croplands declined to $10.8 \%$ of land area, while forests and grasslands increased to $49.6 \%$ and $26.6 \%$, respectively. Reduced agriculture land share in a landscape can be attributed 


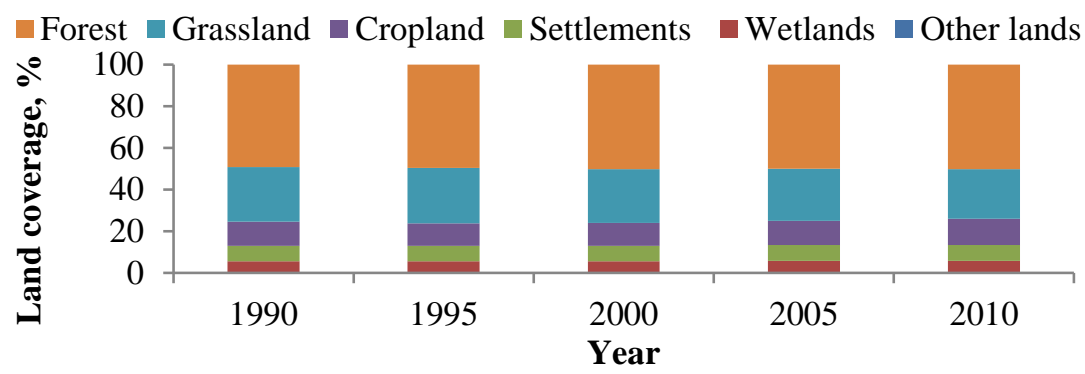

Figure 1. The land cover and land use area change over the observation period.

to farm abandonment that started primarily in 1991, after Latvia gained independence from the former Soviet Union and the agricultural sector became less profitable due to the shift to a capitalist economy, and the breakup of farms into smaller plots (Mathijs \& Swinnen, 1998). Likewise, increase in forest area may also be due to farm abandonment that resulted in the conversion of many cropland fields into young forests (Fonji \& Taff, 2014).

After Latvia's accession to the European Union in following years cropland areas increased while grasslands decreased accordingly. This research shows that according to most recent statistics to II cycle of the NFI in 2011, the dominant land cover

The land use changes in the time period from 1990 to 2011, area gain (ha)

\begin{tabular}{|c|c|c|c|c|c|c|c|}
\hline \multirow{2}{*}{$\begin{array}{l}\text { Time } \\
\text { period }\end{array}$} & \multirow{2}{*}{$\begin{array}{l}\text { Land use categories at the } \\
\text { beginning of the period, ha }\end{array}$} & \multicolumn{6}{|c|}{ Land use categories at the end of the period, thousand ha } \\
\hline & & $\begin{array}{l}\text { Crop- } \\
\text { land }\end{array}$ & $\begin{array}{l}\text { Other } \\
\text { lands }\end{array}$ & $\begin{array}{c}\text { Infra- } \\
\text { structure }\end{array}$ & Forest & Wet-lands & $\begin{array}{l}\text { Grass- } \\
\text { land }\end{array}$ \\
\hline \multirow{6}{*}{ 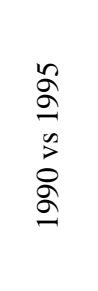 } & Cropland & 0 & 0 & 0.40 & 0.09 & 0 & 43.46 \\
\hline & Other lands & 0 & 0 & 0 & 0.31 & 0 & 0 \\
\hline & Settlements & 0 & 0 & 0 & 0 & 0 & 0.01 \\
\hline & Forest & 0 & 0 & 0.80 & 0 & 1.01 & 0 \\
\hline & Wetlands & 0 & 0 & 0.06 & 0 & 0 & 0 \\
\hline & Grassland & 0 & 0 & 0 & 25.00 & 1.08 & 0 \\
\hline \multirow{6}{*}{ 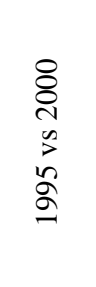 } & Cropland & 0 & 0 & 0 & 0 & 0.40 & 1.57 \\
\hline & Other lands & 0 & 0 & 0 & 0 & 0 & 0 \\
\hline & Settlements & 0 & 0 & 0 & 0 & 0.59 & 1.12 \\
\hline & Forest & 0 & 0 & 0.43 & 0 & 2.91 & 0 \\
\hline & Wetlands & 1.54 & 0 & 0 & 0 & 0 & 0.36 \\
\hline & Grassland & 0 & 0 & 0 & 42.97 & 0 & 0 \\
\hline \multirow{6}{*}{ 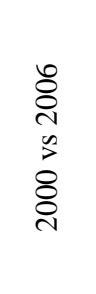 } & Cropland & 0 & 0 & 0 & 0 & 0 & 60.25 \\
\hline & Other lands & 0 & 0 & 0.12 & 0 & 0 & 0 \\
\hline & Urban area & 0 & 0 & 0 & 3.30 & 0.40 & 00 \\
\hline & Forest & 2.47 & 0 & 0 & 0 & 0 & 5.66 \\
\hline & Wetlands & 0 & 0 & 0 & 1.30 & 0 & 2.71 \\
\hline & Grassland & 0 & 0 & 0.26 & 0 & 0 & 0 \\
\hline \multirow{6}{*}{ 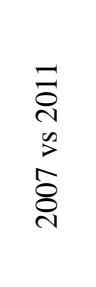 } & Cropland & 0 & 0 & 0 & 0 & 0 & 0 \\
\hline & Other lands & 0 & 0 & 0 & 0 & 0 & 0 \\
\hline & Settlements & 0.55 & 0 & 0 & 0 & 0.33 & 0 \\
\hline & Forest & 0.57 & 0 & 1.94 & 0 & 0 & 0 \\
\hline & Wetlands & 0.11 & 0 & 0 & 2.48 & 0 & 0.01 \\
\hline & Grassland & 61.29 & 0 & 0.68 & 15.0 & 0 & 0 \\
\hline
\end{tabular}


Extrapolated area gain as a result of deforestation from 2012 to 2014

\begin{tabular}{|c|c|c|c|c|c|c|}
\hline \multirow{2}{*}{$\begin{array}{c}\text { Land use categories at the end of the } \\
\text { period. ha }\end{array}$} & \multicolumn{3}{|c|}{$\begin{array}{c}\text { Annually deforested area, thousand } \\
\text { ha }\end{array}$} & \multicolumn{3}{|c|}{$\begin{array}{c}\text { The cumulative deforested area, } \\
\text { thousands ha }\end{array}$} \\
\cline { 2 - 7 } & 2012 & 2013 & 2014 & 2012 & 2013 & 2014 \\
\hline Cropland & 0.11 & 0.11 & 0.11 & 2.91 & 3.02 & 3.13 \\
\hline Other lands & 0 & 0 & 0 & 0.09 & 0.09 & 0.09 \\
\hline Settlements & 0.39 & 0.39 & 0.39 & 3.94 & 4.33 & 4.72 \\
\hline Wetlands & 0 & 0 & 0 & 3.92 & 3.92 & 3.92 \\
\hline Grassland & 0 & 0 & 0 & 4.85 & 4.85 & 4.85 \\
\hline
\end{tabular}

Wood stock changes in transformed areas, $\mathrm{m}^{3} \mathrm{ha}^{-1}$

Table 3

\begin{tabular}{|c|c|c|c|c|c|c|}
\hline \multirow{2}{*}{$\begin{array}{c}\text { Land use categories at the I cycle of } \\
\text { the NFI }\end{array}$} & \multicolumn{6}{|c|}{ Land use categories at the II cycle of the NFI } \\
\cline { 2 - 7 } & Crop-land & Other lands & $\begin{array}{c}\text { Infra- } \\
\text { structure }\end{array}$ & Forest & $\begin{array}{c}\text { Wet- } \\
\text { lands }\end{array}$ & Grassland \\
\hline Cropland & 0 & 0 & 0.23 & -16.55 & 0 & 0 \\
\hline Other lands & 0 & 0 & 0 & 0 & 0 & 0 \\
\hline Settlements & -2.9 & 0 & 0 & 109.07 & -14.29 & 0.01 \\
\hline Forest & -9.24 & 0 & -45.64 & 0 & -72.62 & -47.24 \\
\hline Wetlands & 0 & 0 & 4.12 & 106.97 & 0 & 61.42 \\
\hline Grassland & -0.17 & 0 & 0.54 & 27.16 & 0.79 & 0 \\
\hline
\end{tabular}

and land use category was forest with $50.3 \%$ of total land area, grasslands and croplands occupied a substantial part of the land area (23.7\% and $12.7 \%$, respectively). While wetlands, settlements and other lands together represented a considerably smaller part of all landscape (13.3\% of total area in 2010). Apparently, the common agriculture policy of European Union financial payments to maintain agriculture lands and farming provide a favourable economic environment for land owners (Nikodemus et al., 2010). Our results (counting together croplands and grasslands) were similar to State Land Service reported - agricultural lands, including land currently in cultivation and abandoned areas at present occupy $38.1 \%$ of the land area of Latvia (State Land Service, 2006). A total deforested area for the time period from 1990 according to our results has been declared as 15.2 thousand ha including 4.0 thousand ha that has been deforested as wetlands and other lands which do not count in the GHG emissions. 11.2 thousand ha was transformed into cropland, urban area and fallow area, which is needed to be taken into account, when calculating GHG emissions. In the detailed analysis of land cover and land use, we found that in the time period from 1990 to 1995 the greater changes of the landscape pattern resulted in land transformation among croplands (at the beginning of the period) vs grasslands (at the end of the period) and grasslands vs forest (Table 1.) indicating to land afforestation process. However, grassland transformation into forest land at the end of the period revealed the ongoing afforestation process for the time period from 1995 to 2000.

In the following years, interpretation of the land cover and land use categories shows a trend consistent mainly to croplands and grasslands. In the time period from 2000 to 2005, the cropland area of more than 60 thousand ha was transformed into grasslands. In another study Bara (2007) found an increasing trend of afforestation of croplands starting from 2004, relating with EU co-financing, thus in 2005 nearly five thousand ha of cropland have been afforested, besides most often intending to afforest abounded cropland with productive economic tree species (Bara, 2007). An increase of farming in cropland in the last decade has reflected in the area of cropland that has been increased by 61.3 thousand ha, mainly due to the decrease of grassland area. We assumed that annually deforested area for 2012, 2013 and 2014 is identical to the time period from 2007 to 2011 . The extrapolation of land cover and land use suggested that at the end of the period the total afforested area 
would increase from 15.71 thousand ha in 2012 to 16.71 thousand ha in 2014. The extrapolation results are shown in Table 2.

Changes in mean wood stock (Table 3) between both cycles of the NFI in transformed areas ranged from -72.62 $\mathrm{m}^{3} \mathrm{ha}^{-1}$ (forest lands transformed to wetlands) to $109.07 \mathrm{~m}^{3} \mathrm{ha}^{-1}$ (settlements transformed to forest). Accordingly, application of actualized calculation method would notably improve assessment of biomass dynamics at national scale aiding for reduction of material losses.

\section{Conclusions}

We conclude that most of the deforested areas were not as a result of unsupervised classification and actually have not derived from land use change, but are as biases in classification outcome, related to the colour spectrum changes in Landsat images. As well as identified boundary changes for sample plots in both cycles of the NFI often associated with the tree crown projection of an increase or a different acquisition time of aerial data or angle of an aerial photography which creates a misclassified land use type. Supervised classification showed that in the time period from 1990 to 2014 the deforested area in the sample plots of the NFI had been significantly lower than that was found in previous studies. A comparison of the above-ground biomass in sample plots of the NFI with identified land use change showed that as a result of the deforestation the aboveground biomass accumulation is decreasing less as it has been calculated before.

\section{References}

1. Bara, G. (2007). Problematic character of forest land transformation. In Research for rural development 2007. International scientific conference proceedings, Jelgava, Latvia, 16-18 May, 2007, Latvia University of Agriculture, Jelgava, LLU, 2007, pp. 151-159.

2. Bell, S., Nikodemus, O., Penēze, Z., \& Krūze, I. (2009). Management of Cultural Landscapes: What does this Mean in the Former Soviet Union? A Case Study from Latvia. Landscape Research, 34 (4), pp. 425455. DOI: 10.1080/01426390903020328.

3. Council of Europe. (2000). The European Landscape Convention, Strasbourg.

4. Dhillon, R.S., \& Wuehlisch, von G. (2013). Mitigation of global warming through renewable biomass. Biomass and Bioenergy, 48, pp. 75-89. DOI: 10.1016/j.biombioe.2012.11.005.

5. Fonji, S.F., \& Taff, G.N. (2014). Using satellite data to monitor land-use land-cover change in Northeastern Latvia. Springer plus, 3(1), 61 p. DOI: 10.1186/2193-1801-3-61.

6. Huang, C., Goward, S.N., Masek, J.G., Thomas, N., Zhu, Z., \& Vogelmann, J.E. (2010). An automated approach for reconstructing recent forest disturbance history using dense Landsat time series stacks. Remote Sensing of Environment, 114(1), pp. 183-198. DOI: 10.1016/j.rse.2009.08.017.

7. IPCC (Intergovernmental Panel On Climate Change). (2014). Mitigation of Climate Change. Contribution of Working Group III to the Fifth Assessment Report of the Intergovernmental Panel on Climate Change. In Edenhofer, O., Pichs-Madruga, R., Sokona, Y., Farahani, E., Kadner, S., Seyboth, K., Adler, A., Baum, I., Brunner, S., Eickemeier, P., Kriemann, B., Savolainen, J., Schlömer, S., Stechow, von C., Zwickel, T., \& Minx, J.C. (eds.). Cambridge University Press, Cambridge, United Kingdom and New York, NY, USA, $1454 \mathrm{pp}$.

8. Jansons, J. (2006). Meža resursu monitorings. (Monitoring of forest resources). Working paper of the LSFRI Silava. Salaspils, 18 pp. (in Latvian).

9. Jensen, J.R. (2005). Introductory Digital Image Processing: A Remote Sensing Perspective. Pearson Education, Inc., New Jersey.

10. Jongman, R.H.G. (1996). Ecological and landscape consequences of land use change in Europe. In Jongman, R.H.G. (ed.): Proceedings of the First ECNC Seminar on Land Use Change and its Ecological Consequences, ECNC Publication Series on Man and Nature, Tilburg, vol. 2.

11. Krūmiņš, G. (2012). Tautsaimniecība un naudas politika Latvijā (1945-1991). (Latvian economy and monetary policy (1945-1991)). Latvijas Banka, Rīga, 128 pp. (in Latvian).

12. Kuemmerle, T., Olofsson, P., Chaskovskyy, O., Baumann, M., Ostapowicz, K., Woodcock, C.E., Houghton, R.A., Hostert, P., Keeton, W.S., \& Radeloff, V.C. (2011). Post-Soviet farmland abandonment, forest recovery, and carbon sequestration in western Ukraine. Glob. Change Biol., 17, pp. 1335-1349. DOI: 10.1111/j.1365-2486.2010.02333.x.

13. Main-Knorn, M., Cohen, W.B., Kennedy, R.E., Grodzki, W., Pflugmacher, D., Griffiths, P., \& Hostert, P. (2013). Monitoring coniferous forest biomass change using a Landsat trajectory-based approach. Remote Sensing of Environment, 139, pp. 277-290. DOI: 10.1016/j.rse.2013.08.010. 
14. Mathijs, E., \& Johan, F.M. (1998). The Economics of Agricultural Decollectivization in East Central Europe and the Former Soviet Union. Swinnen Economic Development and Cultural Change, 47, 1, pp. 1-26. DOI: $10.1086 / 452384$.

15. Mander, Ü., \& Palang, H. (1994). Changes of landscape structure in Estonia during the Soviet period. GeoJournal, 33 (1), pp. 45-54. DOI: 10.1007/BF00810135.

16. Mollicone, D., Achard, F., Eva, H., Belward, A., Federici, S., Lumicisi, A., Risso, V.C., Stibig, H.-J., \& Valentini, R. (2003). Land use change monitoring in the framework of the UNFCCC and its Kyoto Protocol: Report on current capabilities of satellite remote sensing technology. European Communities, Luxembourg.

17. Nikodemus, O., Bell, S., Penēze, Z., \& Krūze, I. (2010). The influence of European Union single area payments and less favoured area payments on the Latvian landscape. European Countryside, 2(1/2010), pp. 25-41. DOI: 10.2478/v10091-010-0003-7.

18. Lambin, E.F., Turner, B.L., Geist, H.J., Agbola, S.B., Angelsen, A., Bruce, J.W., \& Xu, J. (2001). The causes of land-use and land-cover change: Moving beyond the myths. Global Environmental Change, 11(4), pp. 261-269. DOI: 10.1016/S0959-3780(01)00007-3.

19. State Land Service of the Republic of Latvia (2006). Land Balance of the Republic of Latvia.

20. Schulp, C.J.E., Nabuurs, G.-J., \& Verburg, P.H. (2008). Future carbon sequestration in Europe-effects of land use change. Agric. Ecosyst. Environ., 127 (3-4), pp. 251-264. DOI: 10.1016/j.agee.2008.04.010.

21. UNFCCC (1997). Kyoto Protocol.

22. Wulder, M.A., Masek, J.G., Cohen, W.B., Loveland, T.E., \& Woodcock, C.E. (2012). Opening the archive: how free data has enabled the science and monitoring promise of Landsat. Remote Sens. Environ., 122, pp. 2-10. DOI: 10.1016/j.rse.2012.01.010. 